\title{
Understanding the Role of Local Tourist Actors as Online Destination Promoters: The “Terras de Trás-os-Montes" Case
}

\author{
Madalena MARINHO ${ }^{1}$, Ricardo Fontes CORREIA ${ }^{2}$ and \\ Elisabete Paulo MORAIS ${ }^{3}$ \\ 1,2,3 Instituto Politécnico de Bragança, Campus de Santa Apolónia, Bragança, Portugal \\ 2,3UNIAG-Applied Management Research Unit, Campus de Santa Apolónia, Bragança, Portugal
}

Correspondence should be addressed to: Ricardo Fontes CORREIA; ricardocorreia@ipb.pt

Received date:11 September 2020; Accepted date:26 January 2021; Published date: 16 April 2021

Copyright (C) 2021. Madalena MARINHO, Ricardo Fontes CORREIA and Elisabete Paulo MORAIS. Distributed under Creative Commons Attribution 4.0 International CC-BY 4.0

\begin{abstract}
Local communities are taking an increasingly major role in communicating a destination in terms of contact with tourists. Based on the assumption that tourist entities and agents are part of this community, it can be assumed that it is necessary for the territorial marketing regulators to promote their involvement. This communication is progressively generated through information and communication technologies (ICT), namely social networks. To analyze the communication contribution of the tourist entities of the Trás-os-Montes lands (a region in the northeast part of Portugal), an analysis was carried out on the online presence and its way of communicating the region. The findings offer relevant insights for the destination managers and policy makers.
\end{abstract}

Keywords: Local community, tourist entities, communication, destination, information and communication technologies (ICT).

\section{Introduction}

The local community of a territory is one of the most important elements in the construction of the territorial offer, since it is the producer and at the same time the consumer of such an offer (Hankison, 2007, Correia \& Brito, 2020). From this community, the tourist actors connected to the hospitality industry have the capacity to promote the destination individually by their actions and promotional tools. If they

Cite this Article as : Madalena MARINHO, Ricardo Fontes CORREIA and Elisabete Paulo MORAIS(2021), “ Understanding the Role of Local Tourist Actors as Online Destination Promoters: The "Terras de Trás-osMontes" Case", Journal of Marketing Research and Case Studies, Vol. 2021 (2021), Article ID 938528, DOI : $10.5171 / 2021.938528$ 
are aware, involved and identified with their region's desired image, these local actors tend to act as true promoters of the region by conveying, in contact with other audiences, messages consistent and appropriate to the characteristics of the offer (García et al., 2012). However, when those tourist actors are not aligned with the destination vision or when they are simply not aware of it, their communication may generate an unclear image for the tourist.

Although the relevance and potential of these local tourist actors in promoting a destination are undeniable, Aitken and Campelo (2011) mention that residents and the local community are often left out of the brand creation process, and therefore, do not participate in the implementation of the territorial marketing strategy (Kavaratzis \& Ashworth, 2008), nor, in turn, are they aligned with the communication of the brand/destination.

Depending on the characteristics of the territory, the local community can vary in size, diversity, dispersion, as well as interests. This heterogeneity makes the alignment of the local community, with the values and territorial vision, a complex driving force.

The relevance of the local tourist actors was amplified with the technological promotional tools that are now available for both companies and individuals. In fact, if, since the 1980s, Information and Communication Technologies (ICT) began to transform tourism (Buhalis \& Law, 2008), they are currently essential in tourism organizations (Drosos, Chalikias, Skordoulis, Kalantonis \& Papagrigoriou, 2017). ICTs are crucial not only as internal sales tools (Martins et al., 2017) but also for interaction, dialogue and connectivity with customers. These technologies have provided tourist actors with instruments to communicate directly and interactively with their audiences, influencing not only their image but also that of the region where they are located.

The main objective of this article is to understand the online presence of tourist entities and how they communicate the destination where they are located. The destination chosen for this analysis comprises 9 municipalities ascribed to the Lands of Trás-os-Montes (a region in the northeast part of Portugal). In a first stage, it was important to understand the presence of various local tourist entities on social networks and how they make use of their websites. Then, the authors analyze whether those entities communicate the destination and whether they do so effectively.

The article is structured as follows. Section 2 offers a comprehensive overview of the theoretical background where the role of the local community in the communication of a destination and the importance of online communication is highlighted. Section 3 presents the methodology used, and in section 4 , the results are discussed. Finally section 5 summarizes the main contributions of the paper and concludes with limitations and suggestions for further research.

\section{Conceptual Background}

\section{The role of the local community in promoting a destination}

Everything that happens territorially (e.g. local production, local brands, security, economic performance and climate change), or carried out by entities related to the territory (such as politicians and public figures) daily communicates the characteristics of the territorial offer, thus having the potential to influence its image and attractiveness (Correia, 2014, Correia \& Brito, 2020). At the same time, some of these entities themselves actively communicate messages about the territory. Hotels communicate characteristics of the territory to which they are related, just as food and landscape. Restaurants are also attached to the local characteristics and may communicate them while promoting their services, the same happens with other actors related to the tourism industry.

The way, in which the locals interact with tourists, even through the menus in the restaurants or the shops windows are 
important sources of communication that should be influenced by the vision and territorial brand as much as possible. Considering the number of the local actors (that can vary from less than one hundred to many thousands), it will be difficult to align them all in a unified territorial vision and to control (or at least influence) their promotional messages.

Given the diversity of the offer elements, one of the most common problems of territorial marketing is the transmission of messages with many appeals, becoming easily confusing and/or inconsistent. Territories should not pretend to have everything, but they should rather be experts in some particular features. Thus, the message/promise associated with the territorial brand should be clear and differentiating. The associated positioning of the territorial brand should serve as a unifying framework by which the territory intends to be recognized while acting as a territorial promise - that is, the brand is an element that fosters the identity of the place (Sousa, Casais \& Pina, 2017). As mentioned above, it is essential that this positioning is identified with the local community, as its realization depends greatly on its behaviour.

As Sousa and Rocha (2019, p. 189) state, "territorial marketing is a fundamental tool in the promotion of places, one that must be present in the strategies of local government representatives, helping and promoting a sustainable economic and social development of the regions". Only by being aware of how the territory intends to communicate externally and the image that it intends to build, can local territorial agents behave in a manner that coincides with that intended image (García et al., 2012). Thus, one of the most important measures of territorial image construction involves communication with territorial agents in order to influence their behavior.

\section{The importance of online communication}

The evolution of the ICT has been notable and the effects of this evolution, applied to tourism, are clearly visible. ICT allows tourists to access accurate and reliable information about the place they want to visit. They also allow reservations to be made more quickly, with easy comparisons of costs and in a much more convenient physical and temporal way. In general, ICTs contribute to a higher quality of service and higher overall satisfaction of guests (Buhalis, 1998).

ICTs enable local people to become more involved in the dissemination of the destination brand, and they do so in a more accessible way (Kavaratzis, Braun \& Zenker, 2013). They facilitate the acquisition of contacts that help in the development of companies, in the acquisition of more capable and cheaper suppliers and even in the dissemination and delivery of products (Buhalis, 2000; Manente \& Minghetti, 2006).

The available technologies now allow the development of solutions to enhance the consumers' experience and increase their involvement with the tourist players as well as the destination. Social networks, with their extremely easy way of allowing people to access and share information, are now one of the main sources of promotion. Social networks have been an increasingly regular practice for the dissemination of the image that entities want to create around a destination brand. In addition, these networks are one of the most pivotal points in the online aspect of marketing management, helping to reach and interact with the target audience (Xiang \& Gretzel, 2010; Kotler et al., 2011). The use of various digital platforms by stakeholders is extremely used and efficient, making "(...) network communication one of the main communication strategies" (Navío-Marco, Ruiz-Gómez \& Sevilla-Sevilla, 2018, p.463).

All of the above highlights the importance of the ICTs in the ability to arouse the interest and desire of tourists in terms of a destination brand. In the same order, this offers a greater notoriety to the territory. Finally, ICTs are a breaking point in the financial and notoriety gap between tourism agents, facilitating contact with the market and providing higher quality of service to smaller companies. Through this greater competitiveness, the region ends 
up gaining more financial and social capacity (Buhalis, 2000).

Adapting this information to the Portuguese territory, the northern region of Portugal has the lowest internet penetration (69\%), and the most purchased services online are accommodation (57\%), transport tickets (44\%) and entertainment tickets (37\%) (ACEPI, 2019). Taking these tourist services into account, it is important for the different tourist entities to be present online and promote the destination in order to attract tourists.

\section{Methodology}

To analyze the online presence of tourist entities and their communication of the destination, quantitative and qualitative approaches were used. In a first stage, the presence of tourism agents on social networks and those who had websites was verified. Regarding the quantitative analysis, it was ascertained how many followers and publications they had in each network. The social networks analyzed were Facebook, Instagram and Youtube, as they are the most used by Internet users (Marktest, 2019).

In a second phase, which corresponds to the qualitative approach, the objective was to understand if the entities communicated their destinations. In the case of communicating, an analysis was made to find out on which platform those entities communicate, how they communicate, and which the target themes of communication are. The analysis covers the periodic interval from January 1, 2020 to May 31, 2020.

\section{Sample Selection Criteria}

For the selection of the sample, the territorial unit NUT III was considered which corresponds to the Lands of Trás-osMontes. This region in the north of Portugal is composed of nine municipalities: Alfândega da Fé, Bragança, Macedo de Cavaleiros, Miranda do Douro, Mirandela, Mogadouro, Vila Flor, Vimioso and Vinhais. The tourist entities of these counties were selected based on three categories: accommodation, catering and activities. The accommodation and restaurants were taken from the book Boa Cama, Boa Mesa 2020 (Expresso, 2020). This book contemplates several criteria for the selection of the spaces awarded with the reference, such as: considered ambassadors of the region's gastronomy; users and promoters of local products; recognized in the region for their active role. This book is also known to contain the best accommodation and restaurants in each region of Portugal. As far as tourist activities are concerned, these were chosen based on the website of each City Hall under analysis and the Trip advisor platform.

\section{Sample}

In total, 29 entities from the 9 municipalities were analyzed: 10 accommodations; 9 restaurants and 10 entities with tourist activities.

Table 1 shows the nine municipalities that correspond to the Lands of Trás-os-Montes, the data on the arrival of guests in 2018 (INE, 2018), the tourist entities analyzed and the due designation of abbreviations in legend for better interpretation of the data. It is possible to observe that the municipality of Bragança presents a larger number of entities for analysis. This is justified because it is the capital of the district and the target of demand for more tourists. 
Table 1: Sample of tourist entities analyzed

\begin{tabular}{|c|c|c|c|}
\hline Counties & $\begin{array}{l}\text { Guest arrivals } \\
(2018)\end{array}$ & Tourist entities & Denomination \\
\hline Alfândega da Fé & 7822 & Bela Vista Silo Housing & $\mathrm{A} 1$ \\
\hline \multirow{11}{*}{ Bragança } & \multirow{11}{*}{65243} & Pousada de Bragança & $\mathrm{A} 2$ \\
\hline & & Bétula Studios & A3 \\
\hline & & Quinta da Rica Fé & A4 \\
\hline & & Restaurante G & R1 \\
\hline & & D. Roberto & $\mathrm{R} 2$ \\
\hline & & 0 Abel & R3 \\
\hline & & 0 Geadas & $\mathrm{R} 4$ \\
\hline & & TascaZéTuga & R5 \\
\hline & & Anda D'I & ATV1 \\
\hline & & Nordeste Park & ATV2 \\
\hline & & Montesinho Aventura & ATV3 \\
\hline \multirow{2}{*}{$\begin{array}{l}\text { Macedo } \\
\text { Cavaleiros }\end{array}$} & \multirow{2}{*}{6411} & Solar do Morgado Oliveira & A5 \\
\hline & & Brasa & R6 \\
\hline \multirow{3}{*}{ Miranda do Douro } & \multirow{3}{*}{25587} & Casa dos Edras & A6 \\
\hline & & Casa Belharino & A7 \\
\hline & & Douro Pula Canhada & ATV4 \\
\hline \multirow{5}{*}{ Mirandela } & \multirow{5}{*}{22936} & Dona Fina Guest House & A8 \\
\hline & & Flor de Sal & R7 \\
\hline & & Maria Rita & R8 \\
\hline & & Naturthoughts & ATV5 \\
\hline & & Anitudes & ATV6 \\
\hline \multirow{2}{*}{ Mogadouro } & \multirow{2}{*}{1975} & Casa das Quintas & A9 \\
\hline & & A Lareira & R9 \\
\hline Vila Flor & 3136 & Quinta Barracão da Vilariça & A10 \\
\hline \multirow{2}{*}{ Vimioso } & \multirow{2}{*}{1366} & P.I.N.T.A & ATV8 \\
\hline & & Coordenadas de aventura & ATV9 \\
\hline Vinhais & 6712 & ParqueBiológico de Vinhais & ATV10 \\
\hline
\end{tabular}

\section{Results}

In the first phase, the analysis aimed at knowing the online presence of the selected tourist entities, and out of 29 , only
2 do not have any online presence (2 restaurants). Regarding the most used platform, Facebook stands out (26 entities), 17 entities are present in Instagram and have a website (graph 1). 


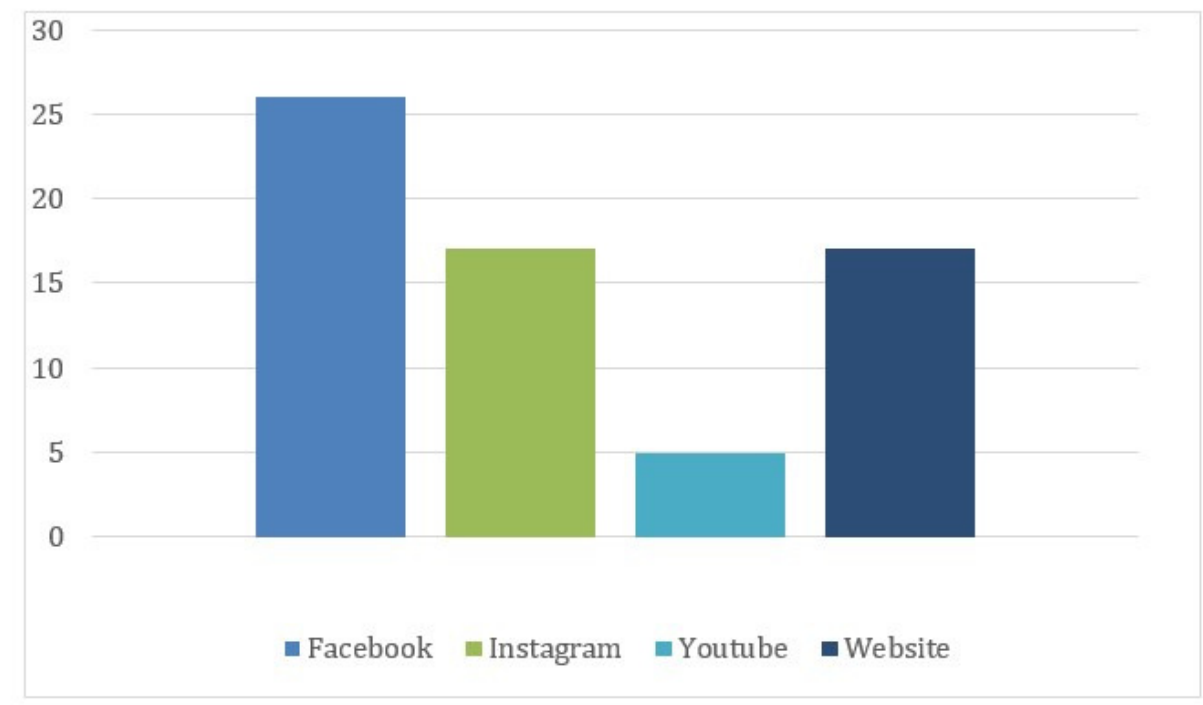

\section{Graph 1: Online presence of tourist entities}

Although most of the entities are present on the platforms presented, many of them, during the analysis period, did not interact with their followers. It can also be noted that 8 entities placed between 0 and 5 posts (in five months) on Facebook, this being an extremely low number compared to other entities.
The followers of the two most used social networks (Facebook and Instagram) were also studied to know their impact on these same networks (graph 2). The entities with more followers on Facebook correspond to restaurants (6 have more than 3000 followers) and activities ( 2 have more than 3000 followers).

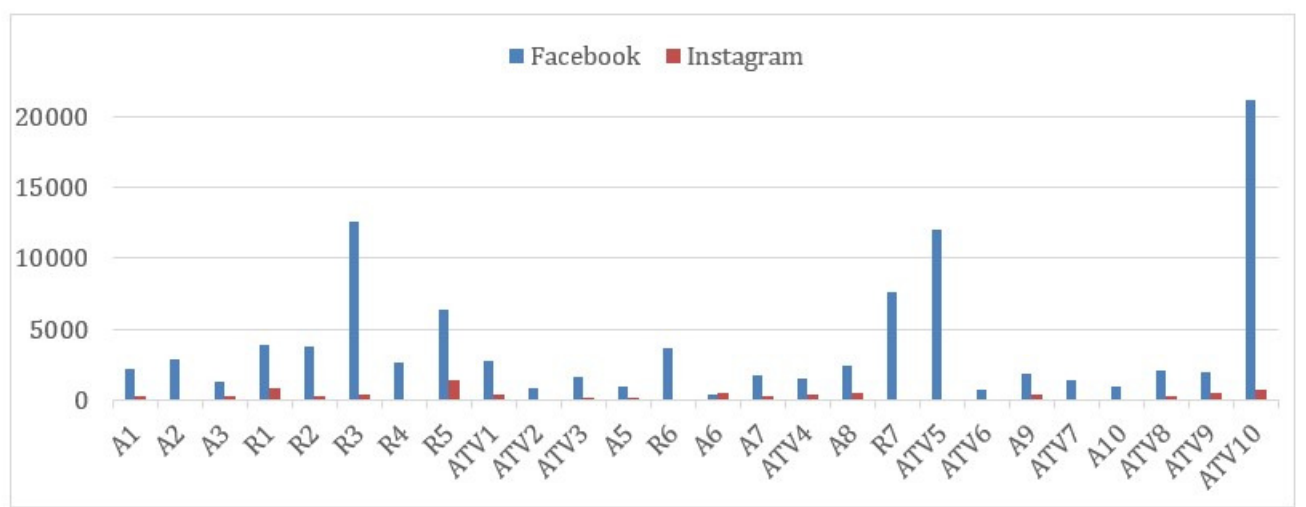

Graph 2: Followers of social networks of tourism entities

The analysis proceeded with the objective to find which of the 29 entities communicate the destination. In a first stage, the existence of some type of content on the platforms that portrayed the destination was verified. Of the 29 entities analyzed, only 18 communicate the destination. The results obtained show that

Madalena MARINHO, Ricardo Fontes CORREIA and Elisabete Paulo MORAIS, Journal of Marketing Research and Case Studies, DOI : 10.5171/2021.938528 
the most used platform to communicate is Facebook, and of the 18 that communicate, 15 use this social network (graph 3). It can also be seen that 10 entities have information about the destination on the website, information that corresponds to static pages.

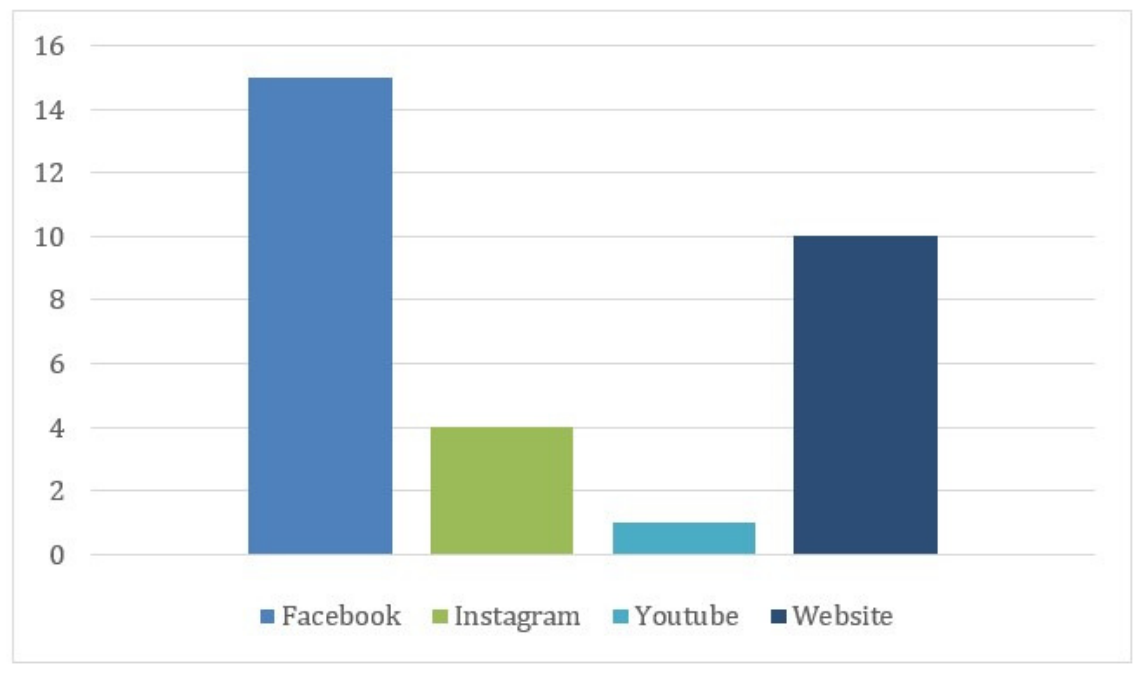

Graph 3: Platforms where tourist entities communicate the destination

The different forms of sharing chosen by the entities to communicate the destination were also analyzed. Four categories were considered: photos, sharing, text and videos. As for sharing, it is important to mention that it consists of shared contents from other people, blogs, or news. Graph 4 shows that the most used way to communicate destinations are the photos. This represents the identity of a destination and can trigger emotions and desires to visit a destination (Pérez-García, 2020). Many of the photographs used are accompanied by an explanatory text about the content that is the target of the communication. 


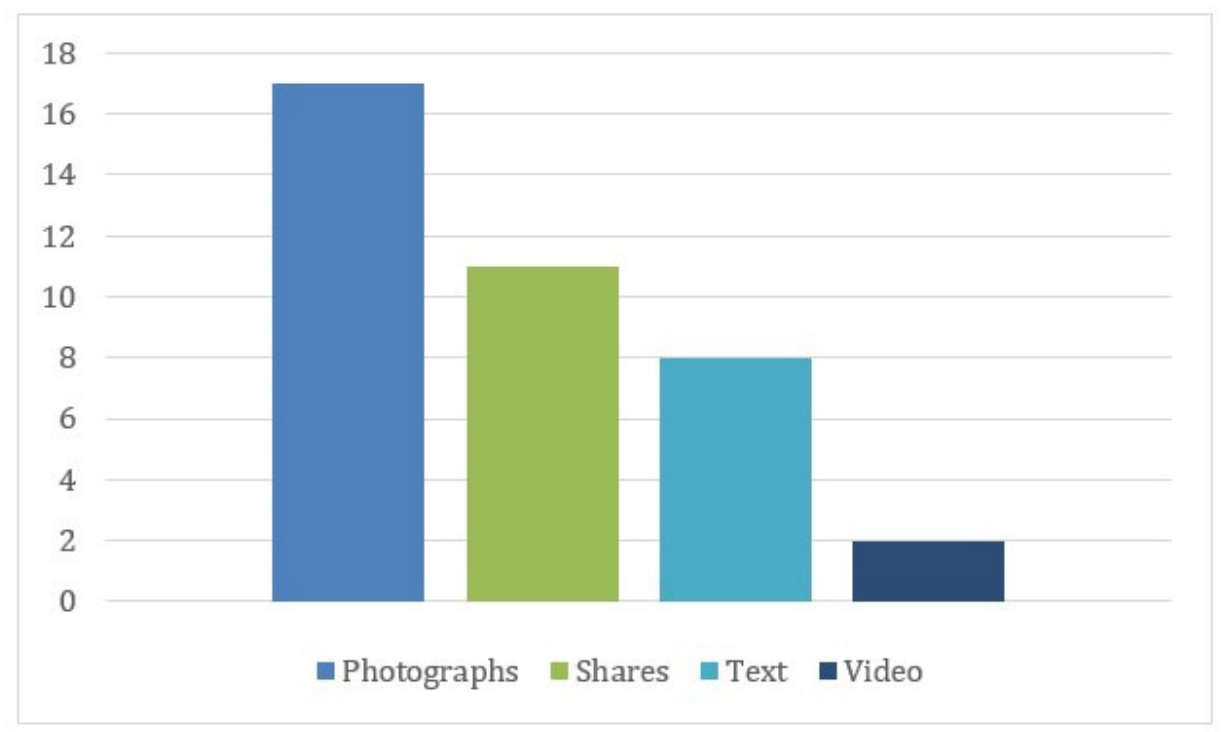

Graph 4: Ways used by tourist entities to communicate the destination

Regarding the themes addressed by the entities, they were categorized based on the nine dimensions/attributes of image perception of a destination, proposed by Beerli and Martín (2004). The categories are the following: natural resources; general infrastructure; tourist infrastructure; leisure and recreational tourism; culture, history, and heritage; natural environment; social environment; atmosphere of the place; political and economic factors. Despite the existence of 9 dimensions, for the following analysis, only 4 categories were considered, since they are related to the data under study.

- Natural resources: time, beaches, flora and fauna, parks and natural reserves. - Tourist infrastructures: hotels, restaurants, bars, discotheques, tourist office, etc.

- Leisure and recreational tourism: entertainment and sports activities.

- $\quad$ Culture, history and art: museums, monuments, gastronomy, religion, customs, etc.

Therefore, of the communicated themes, the category corresponding to natural resources, namely the theme Natural Park of Douro International is the most communicated. Soon after, the category corresponding to culture, history and art stands out, being the most communicated events of the region as well as local gastronomy..

Facebook was chosen for a more detailed analysis, as it is the most used platform by entities. The purpose of this analysis is to know the activity of the entities in this social network and the frequency of their communication of destinations. The quantification of this frequency was made based on the total of publications in the period stipulated for the analysis. From this, it is concluded that only 15 tourist entities communicate through this social network (graph 5).

Although many entities communicate the destination, it is important to understand the number of the posts registered during a period of five months, and how many of these posts correspond to the communication of the destination. 


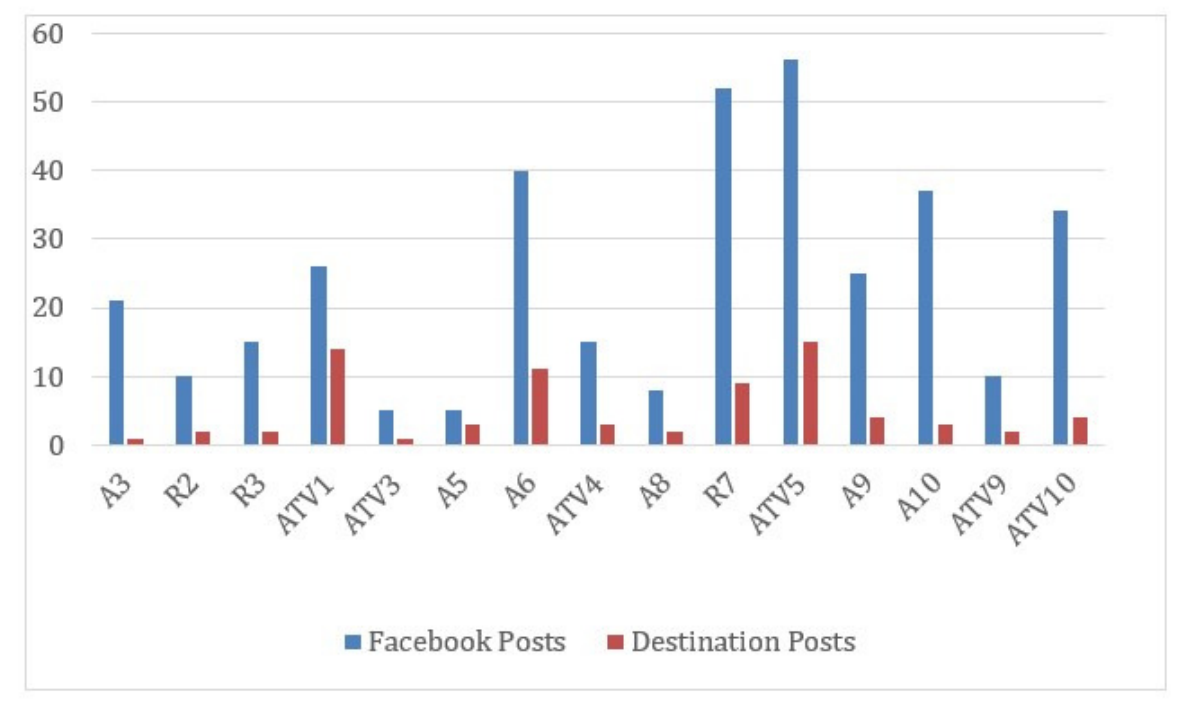

\section{Graph 5: Comparison between the total of Facebook posts and the posts that communicate the destination}

This importance is related to the idea that an entity that makes several posts but only communicates the destination once, is in a situation substantially different from another that communicates the territory weekly, which is here the intended objective to improve the capacity and notoriety of the destination brand. For graph 5, only tourist entities that communicate the destination were considered.

The most active entities on Facebook are a restaurant and a tourist entertainment company in the municipality of Mirandela, respectively. It is also these two entities that communicate the destination the most, followed by ATV1 and A6.

The analysis made shows that about $62 \%$ (18) of the analyzed tourist entities communicate the destination. Although this number represents more than half of the total sample, it should be taken into account that $16.6 \%$ (3) of these entities communicate through a website, where the information is on a static page, with no effective contribution. The remaining entities communicate through Facebook and Instagram. However, during the five months analyzed, only 4 entities communicated the destination more than five times.

\section{Final Considerations}

It should be emphasized that, based on some studies (Correia \& Brito, 2017; Kavaratzis, Braun \& Zenker, 2013), it can be concluded that uncontrolled sources, where tourist entities are included, are more significant and effective in communicating a destination. This is because the less controlled the information is, the more credibility and influence it will have on the creation of the image of the destination, with consumers (tourists). As Correia and Brito (2017, p.819) state "(...) the territorial offer is co-produced by a multiplicity of entities, each one of them will be able to function through its behaviors and activities as a communication element of the territory".

The use of technologies has allowed the various entities to have a lower dependence on intermediary companies for the distribution and communication of their products (Buhalis, 2000), allowing a better interaction between various tourism agents and an integral marketing communication. 
The study made it possible to verify the complexity that involves the communication of a destination by local entities. It is then concluded that it is not enough to sporadically communicate a destination to attract tourists' attention; the message communicated must be constant, clear and attractive. However, most tourist entities in Trás-os-Montes do not communicate the destination regularly.

Most tourist entities are small and micro enterprises, a number that is even more intensified in the region under study. This type of entity suffers from a greater difficulty in accessing social capital and technological investments. However, according to Lee and Hallak (2020), small and micro enterprises have the capacity to become competitive through the appropriate use of online platforms and the support of destination governments and tourism associations in connecting all these enterprises.

This article has some limitations, particularly regarding the selected sample. Not all the entities chosen matched the top demand in terms of tourism.

Another limitation in this study relates to the method of analysis - observation. This method, when applied by different researchers, may eventually generate different collected data, since different points of view may lead to the consideration of different types of posts as a form of communication. However, it should be made clear that there has been an effort for the analysis to be totally impartial and built from the perspective of the tourist. For example, some posts were not considered "communicative" because the photographs were not visually perceptible.

For a future line of research, it would be interesting to consider a larger sample of tourist entities in order to draw more assertive conclusions. It would also be interesting to cover other types of tourist entities such as: museums, regional product shops, bars, tourist services etc. as well to analyze the alignment between the messages conveyed by the touristic actors and the position and vision of the destination brand.

\section{References}

- ACEPI - Associação da Economia Digital (2019). Estudoanual da economia e da sociedade digital.

- Aitken, R., \&Campelo, A. (2011). The four Rs of place branding.Journal of Marketing Management, 27 (9-10), 913-933.

- Beerli, A., \& Martín, J. D. (2004). Factors influencing destination image.Annals of Tourism Research, 31(3), 657-681.

- Buhalis, D. (1998). Strategic use of information technologies in the tourism industry.Tourism Management, 19(5), 409-421.

- Buhalis, D. (2000). Marketing the competitive destination of the future. Tourism Management, 21(1), 97-116.

- $\quad$ Buhalis, D., \& Law, R. (2008). Progress in information technology and tourism management: 20 years on and 10 years after the internet - the state of eTourism research. Tourism Management, 29(4), 609-623

- Correia, R. (2014). Marketing Territorial. In C. Brito e P. Lencastre (Ed.).NovosHorizontes do Marketing, (pp.210-224). Lisboa: Publicações D. Quixote

- Correia, R. \& Brito C. (2020). People: The Most Important Marketing Asset of Territories.Journal of Marketing Research \& Case Studies p.1-10. ISSN 2165-7009.

- Correia, R. \&Brito, C. (2017). Envolvimento da comunidade - A condiçãonecessáriapara o sucesso da marca regional.RevistaTurismo\&Desenvolvime nto, (27/28), 815-824.

- Drosos, D., Chalikias, M., Skordoulis, M., Kalantonis, P., \&Papagrigoriou, A. (2017). Thestrategic role ofinformationtechnologyintourism: The case of global distributionsystems. Tourism, CultureandHeritagein a SmartEconomy, 207-219.

- Expresso, R. (2020).Boa Cama Boa Mesa.Lisboa: Impresa Publishing. 
- García, J., Gómez, M. \& Molina, A. (2012). A Destination-Branding Model: An empirical analysis based on stakeholders.Tourism Management, 33(3), 646-661

- Hankison, G. (2007). The Management of Destination Brands: Five guiding principles based on recent developments in corporate branding theory.Brand Management, 14(3), 240254.

- INE, (2018). AnuárioEstatístico da Região Norte.Lisboa: InstitutoNacional de Estatística.

- Kavaratzis, M., \& Ashworth, G. (2008). Place marketing: how did we get here and where are we going? Journal of Place Management and Development, 1(2), 150-165.

- Kavaratzis, M., Braun, E., \&Zenker, S. (2013). My city-my brand: the role of residents in place branding. Journal of Place Management and Development 6 (1), 18-28.

- Kotler, P., Bowen, J. T., Makens, J. C., García, J., \& Flores, J. (2011).Marketing turístico (5 ${ }^{\mathrm{a}}$ Ed.). Madrid: Prentice Hall.

- Lee, C., \&Hallak, R. (2020). Investigating the effects of offline and online social capital on tourism SME performance: A mixed-methods study of New Zealand entrepreneurs. Tourism Management, 80, 104128.

- Martins, J., Gonçalves, R., Branco, F., Barbosa, L., Melo, M., \& Bessa, M. (2017). A multisensory virtual experiencemodel for thematictourism: A

Portwinetourismapplicationproposal. JournalofDestination Marketing \&Management 6 (2017) p. 103-109 http://dx.doi.org/10.1016/j.jdmm.201 7.02.002
- Manente, M., \&Minghetti, V. (2006).Destination management organizations and actors. In Buhalis, D. \& Costa, C. (Eds). Tourism business frontiers, (pp. 228-266). Routledge.

- Marktest, (2019). OsPortugueses e as RedesSociais 2019.Lisboa: GrupoMarktest. Available at: https://www.marktest.com/wap/a/gr $\mathrm{p} / \mathrm{p} \sim 96 . \operatorname{aspx}$

- Navío-Marco, J., Ruiz-Gómez, L. M., \&Sevilla-Sevilla, C. (2018).Progress in information technology and tourism management: 30 years on and 20 years after the internet-Revisiting Buhalis\& Law's landmark study about eTourism. Tourism Management, 69, 460-470.

- Pérez-García, A. (2020). La fotografíaturística de interacciónicónica: identidad de representaciónsimbólica de imagen personal en el destino. InvestigacionesTurísticas (19), 186212.

- $\quad$ Sousa, B., Casais, B. \&Pina, G. (2017), "The Influence of Territorial Branding on the Tourist Consumer Predisposition: The Cape Verde Case", European Journal of Applied Business and Management, Special Issue, 324335.

- Sousa, B. and Rocha, A. (2019), "The role of attachment in public management and place marketing contexts: A case study applied to Vila de Montalegre (Portugal)", International Journal of Public Sector Performance Management, 5(2), 189205.

- $\quad$ Xiang, Z., \&Gretzel, U. (2010). Role of social media in online travel information search.Tourism Management, 31(2), 179-188. 